\title{
Model of Legal Protection Against Children of Sexual Harassment According to Qanun Jinayah Law in Aceh Indonesia
}

\author{
Muhammad Nur* Harun Yusrizal \\ Law Faculty, University of Malikussaleh Indonesia
}

\begin{abstract}
Child crime should not be equated with adult crime. Children have their characteristics, for that, should be handled with care. Given that legal protection of children is still weak in practice, more research is needed on the Model of Protection of Children of Sexual Abusers Based on Qanun Jinayah in Aceh. This study is an analytical descriptive study on the Model of Legal Protection against Child Sexual Abusers Based on Qanun Jinayah in Aceh. Considering that legal protection for children is still weak in practice, further research is needed on the Model of Legal Protection Against Child Perpetrators of Sexual Harassment Based on Qanun Jinayah in Aceh. This research is descriptive-analytical research on the Model of Legal Protection Against Child Perpetrators of Sexual Harassment Based on Qanun Jinayah in Aceh. Descriptive research aims to precisely describe the traits of an individual, circumstance, symptom, or group in society. The juridical review is used with the consideration that the applicable legal rules can be influenced by various factors, such as the society it governs, the developing culture, and the law and society influencing each other, while the empirical review is intended to see the law from reality. Based on the results of the study, it can be seen that the legal protection model for child sexual abuse perpetrators according to the jinayah legal qanun is in the form of protection through diversion, protection against the application of caning sanctions, and protection of other children's rights, both the right to education, the right to receive religious guidance and right to work. It is hoped that the Aceh government will improve the Qanun on Jinayah Law, especially on child protection, so that the material in the Qanun on Jinayah Law can be applied consistently by law enforcers.
\end{abstract}

Keywords: Model, Legal Protection, Child Abuser, Jinayah Aceh Law, Indonesia

DOI: $10.7176 / \mathrm{JLPG} / 117-07$

Publication date: January $31^{\text {st }} 2022$

\section{Introduction}

Violation of the law committed by children is a form of child delinquency which is a characteristic of human life in the period of growth. Child delinquency means that in addition to behavior that violates the law, it also violates moral values. Child delinquency has a conflicting purpose, namely, the act or behavior is contrary to the values or social norms that exist in their environment. ${ }^{1}$

The term child delinquency according to the Law of the Republic of Indonesia Number 11 of 2012 concerning the Criminal Justice System of Children mentioned that children who face the law, one of the forms is the child of the perpetrator of the crime. Children as perpetrators of crime are still given legal protection. Therefore the unlawful actions of a child should not be equated with crimes committed by adults, because he has his characteristics. The handling should be done differently from the handling of adult crimes.

Child criminal law aims to heal the psychiatric state of children who have been shaken by the criminal acts they have committed. Therefore, the purpose of the criminal is not merely to punish the guilty child, but to foster and resuscitate the child who has made a mistake or has committed a deviant act. This is important considering that what he has done is wrong that violates the law. A criminal conviction is not the only attempt to process a child who has committed a criminal offense. ${ }^{2}$

Article 59 of the Law of the Republic of Indonesia Number 35 of 2014 concerning Child Protection determines:

Special Protection for Children in conflict with the law as referred to in Article 59 of the Law of the Republic of Indonesia Number 35 of 2014 concerning Child Protection, paragraph (2) letter b is carried out through:

a. liberation from torture, punishment, or other cruel, inhuman, and degrading treatment;

\footnotetext{
Ny. Singgih Gunarso dan Singgih Gunarso. 1985, Psikologi Remaja, Gunung Mulia, Jakarta, p. 30. The term child delinquency with the enactment of the Law of the Republic of Indonesia Number 11 of 2012 concerning the Criminal Justice System of Children, is called a child who is in conflict with the law. Look Unayah, Unung and Muslim Sabarisman, The Phenomenon of Juvenile Delinquency and Criminality, "Sosio Informa", 1.2. (2016). Siregar Risdalina, Pengaruh Mass Media Terhadap Kenakalan Remaja Ditinjau dari Psikologi Kriminal, "Jurnal Ilmiah Advokasi, 5.2 (2017), p. 94-109.

${ }^{2}$ Marlina. 2009, Peradilan Pidana Anak di Indonesia, Refika Aditama, Bandung, p. 158 see also, Rahayu, Sri. "Diversi Sebagai Alternatif Penyelesaian Perkara Tindak Pidana Yang Dilakukan Anak Dalam Perspektif Sistem Peradilan Pidana Anak." Jurnal Ilmu Hukum Jambi 6.1 (2015): 43317. see also, Sekhroni, Sekhroni. "Criminal Liability dan Diversi Terhadap Tindak Pidana Anak dalam Sistem Peradilan Anak di Indonesia." UNIFIKASI: Jurnal Ilmu Hukum 3.1 (2016). Wahyudi, Dheny. "Perlindungan terhadap anak yang berhadapan dengan hukum melalui pendekatan restorative justice." Jurnal Ilmu Hukum Jambi 6.1 (2015): 43318.
} 
b. avoidance of the death penalty and/or life imprisonment;

Protection of children who violate criminal law, first; note that the main focus in the legal system dealing with child offenders; Especially in criminal justice should emphasize or prioritize the welfare of children and principles to avoid the use of solely punitive sanctions. Second, the principle is a tool to curb the use of punitive sanctions in the sense of retaliating solely. ${ }^{1}$

The rationale of juvenile criminal justice, namely; Children who commit violations of criminal law should not be judged as criminals. But it should be viewed as a small creature that needs help. The juridical approach to children should prioritize persuasive-educative and approach (psychiatric/psychological) that is as far as possible avoid legal processes that are solely punishing, mental degradation, and discouragement and avoid stigmatization processes that can inhibit the process of development of maturity and independence in a reasonable manner. ${ }^{2}$ Therefore, when talking about something that is best for the child, then the keyword is in a way that is not punishing. ${ }^{3}$

Violations of law by children in Aceh Province today, especially the crime of sexual abuse are alarming but juridically in Aceh Province has been applied Qanun Jinayah Law in the enforcement of crimes, so that against children is also enforced Qanun Jinayah Law. Based on data shows the criminal acts of sexual violence committed by children are relatively many. Throughout 2019 , there were 280 cases of sexual violence against children, recorded in the Aceh Office of Women Empowerment and Child Protection (BP3A).

Sanctions that can be applied to children who commit crimes are stipulated in Article 67 Qanun of Aceh Jinayah Law. The child offender is threatened with corporal punishment or imprisonment. The regulation of sanctions against children stipulated in Qanun Aceh Number 6 of 2014 concerning Jinayah Law. In Article 67, it is stated that: If the child who has reached the age of 12 (twelve) years but has not reached the age of 18 (eighteen) years or unmarried commits an act of finger, then the child can be subject to Uqubat at most 1/3 (onethird) of the 'Uqubat that has been determined for adults and/or returned to his parents/guardians or placed in a place provided by the Government of Aceh or the Regency or City Government. The policy of Qanun Jinayah Law which imposes criminal sanctions for deprivation of independence (imprisonment) against children or other bodily punishment (flogging), is not following child protection efforts. Legally, the policy of criminalization of children is an act of violating the basic right to fair legal protection and certainty and equal treatment before the law. ${ }^{4}$

Juridically against the child perpetrator of a criminal act, there is still a waiver of his right to protection. Base on the explanation in the background above, it can be formulated the problem, how is the model of legal protection against child sexual abusers based on the Jinayah Law Qanun in Aceh?

\section{Research Methods}

This research is an empirical juridical study on the Model of Legal Protection against Children of Sexual Abusers Based on Jinayah Law Qanun in Aceh. Juridical review is used with the consideration that the rules of applicable law can be influenced by various factors, both the society it regulates, the culture that develops, and the laws and societies that each other. Empirical studies are meant to look at the law from reality. ${ }^{5}$ The source of the research data used is primary data in the form of interviews with respondents. The respondents consisted of:

1. Banda Aceh City Police Investigator one person,

2. The prosecutor at banda Aceh City State Prosecutor one person,

3. Syar'iyyah Court Judge of Banda Aceh City one person,

4. Aceh Besar Police Investigator one person.

5. Prosecutor at the Aceh Besar State Prosecutor one person,

6. Syar'iyyah Court Judge Jantho one person

7. Syar'iyyah Kuala Simpang Court Judge one person

Data analysis in this study is by qualitative method, which is to interpret quality about the opinions or

\footnotetext{
${ }^{1}$ Maidin Gulto m, Perlindungan Hukum Terhadap Anak, Refika Aditama, Bandung, 2008, p. 2. See also Hambali, Azwad Rachmat. "Penerapan diversi terhadap anak yang berhadapan dengan hukum dalam sistem peradilan pidana." Jurnal Ilmiah Kebijakan Hukum 13.1 (2019): 15-30. See also Hartoyo, Nuri, Herman Fikri, and Adi Purnama. "Perlindungan Hukum Terhadap Anak Yang Berhadapan Dengan Hukum Melalui Restoratif Justice." Lex Librum: Jurnal Illmu Hukum (2020): 102-113

${ }^{2}$ Waluyadi, Hukum Perlindungan Anak, Mandar Maju, Bandung,2009,p. 46. See also, Yudaningsih, Lilik Purwastuti, and Sri Rahayu. "Reformasi Perlindungan Hukum terhadap Anak Sebagai Pelaku Tindak Pidana dalam Peradilan Pidana di Indonesia." INOVATIF| Jurnal Ilmu Hukum 6.2 (2013)

${ }^{3}$ Prasetyo, Harsanto Diyan. Kebijakan Hukum Pidana Dalam Upaya Perlindungan Hukum Terhadap Anak Pelaku Tindak Pidana (Juvenile Deliquency). dissertation, Universitas Diponegoro, 2012. See also Simatupang, Taufik H. "Sistem Hukum Perlindungan Kekayaan Intelektual dalam rangka Meningkatkan Kesejahteraan Masyarakat." Jurnal Penelitian Hukum De Jure 17.2 (2017) p. 195.

${ }^{4}$ Hadi Supeno. 2010, Kriminalisasi Anak, Gramedia Pustaka Utama, Jakarta, p.128 see also Mushaddiq, Nur Wahid. Tinjauan Yuridis terhadap Eksploitasi Seksual pada Anak Berdasarkan Hukum Perlindungan Anak dan Hukum Islam. dissertation, Universitas Islam Negeri Alauddin Makassar, 2015.see also Akbar, Amellia Putri. Pelanggaran HAM dalam Pemidanaan (Perbandingan Hukuman Cambuk dengan Penjara). dissertation, UIN Ar-Raniry Banda Aceh, 2017.

${ }^{5} I b I d .$, p. 9.
} 
responses of respondents, then explain it in full and comprehensively about various aspects related to the subject matter. ${ }^{1}$

\section{Discussion}

\subsection{Child Protection}

Children are defined as young humans or immature humans. ${ }^{2}$ Law of the Republic of Indonesia Number 11 of 2012 concerning the Criminal Justice System of Children, Article 1 number 3 affirms that children who conflict with the law which is further called a child are a human who has aged 12 (twelve) years but has not been 18 (eighteen) years old who is suspected of committing a criminal act.

According to the Islamic Penal Code, a woman has mukallaf when she is fifteen years old, which has shown the development of her adult body shape. As for the taklif of men, based on the opinion of scholars if he has had a dream (having sex with women secreting sperm). ${ }^{3}$ Taklif is old enough to be of birth, and signs of adult men appear in sons, adult signs appear in women in girls. This is a natural adult, which usually does not exist before the age of 12 years in men, and 9 years in women. The age limit of the child when he has dreamed then he has puberty. One of the signs of puberty is that it is fifteen years old. ${ }^{4}$

Child protection is any activity to ensure and protect the child and his rights to live, grow, develop, and participate, optimally following the dignity of humanity, and to be protected from violence without discrimination. The recognition and legal protection of various rights and freedoms of the child are intended to fulfill various interests related to the welfare and future of the child. ${ }^{5}$

Special protection is the protection provided to children in emergencies, children facing the law, children from minority and isolated groups, children who are exploited economically and/or sexually, the Law of the Republic of Indonesia No. 35 of 2014 on Child Protection affirms that the accountability of parents, families, communities, governments, and countries is a series of activities that are carried out continuously to protect the rights of children.

\subsection{Sexual Harassment}

Child sexual abuse can be defined as a relationship or interaction between a child and an older person or child, more reason or adult such as a stranger, sibling, or parent where the child is used as an object of consent for the sexual needs of the perpetrator. ${ }^{6}$ Criminal acts of sexual harassment are committed by using coercion, threats, bribery, deception, or pressure.

\subsection{Qanun Jinayah Law}

Jinayah law is the terminology used in Islam to refer to Islamic criminal law. The term law comes from Arabic, namely from the word hakama, yahkumu, hukmun, which means preventing or rejecting, namely preventing injustice, preventing injustice, preventing persecution, and rejecting other forms of disobedience. ${ }^{8}$ Jinayah is the

\footnotetext{
${ }^{1}$ Ronny Hanitjo Soemitro.2005. Metode Penelitian Hukum.Jakarta, Ghalia Indonesia, p. 93

${ }^{2}$ Poerwdarminta. 1984, Kamus Umum Bahasa Indonesia, Balai Pustaka; Armico, Jakarta, p. 25.see also Fitriani, Rini. "Peranan Penyelenggara Perlindungan Anak Dalam Melindungi Dan Memenuhi Hak-Hak Anak." Jurnal Hukum Samudra Keadilan 11.2 (2016): 250358 .

${ }^{3}$ Muhammad Ismail Al-Kahlani. 1960, Subul as-Salam. Syarh Bulugh al- Maram, juz III, Mustafa al-Babi al-Halabi, Mesir, 1960, p. 181 see also Nahrowi, Nahrowi. "Penentuan Dewasa Menurut Hukum Islam Dan Berbagai Disiplin Hukum." Kordinat| Jurnal Komunikasi Antar Perguruan Tinggi Agama Islam 15.2 (2016): 253-274. See also Lukman"Penentuan Dewasa Menurut Hukum Islam Dan Berbagai Disiplin Hukum." Kordinat| Jurnal Komunikasi Antar Perguruan Tinggi Agama Islam 15.2 (2016): 253-274. See also Lukman, Lukman. "Relevansi Hukum Islam Dan Hukum Positif Tentang Usia Dewasa Dalam Perkawinan."Qiyas: Jurnal Hukum Islam dan Peradilan 4.1 (2019).

${ }^{4}$ Sayyid Sabiq, Fiqh Sunnah, Jilid. 3, Toha Putra, Semarang, 1986, p.. 410. See also Aperani, Rika. "Hukum Pertanggungjawaban Pidana Anak Dalam Batasan Usia (Studi Analisis Hukum Pidana Islam danUndang-Undang Nomor 11 Tahun 2012)." (2020). See also Hermawati, Nety. "Kejahatan Anak Menurut Hukum Pidana Positif dan Hukum Pidana Islam." Istinbath: Jurnal Hukum 12.1 (2015): 82-132.

${ }^{5}$ Meily dkk., Perlindungan Hukum Terhadap Hak Anak Pelaku Tindak Pidana Pemerkosaan Dalam Sistem Peradilan Pidana, e Jurnal Katalogis, Vol. 5, No. 2, Februari 2017. See also Prasetyo, Andik. "Perlindungan Hukum Bagi Anak Pelaku Tindak Pidana."Mizan: Jurnal Ilmu Hukum 9.1 (2020): 51-60. See also Mahfiana, Layyin. "Perlindungan hukum Terhadap tersangka anak sebagai upaya melindungi hak anak." Jurnal Muwâzâh 3.1 (2011).

${ }^{6}$ Suseni, Komang Ayu, and I. Made Gami Sandi Untara. "upaya penanggulangan tindak pidana kekerasan seksual terhadap anak."Pariksa 1.1 (2020). Rohmah, Nurur, et al. "Kekerasan Seksual Padaanak: Telaah Relasi Pelaku Korban Dan Kerentanan Pada Anak."Psikoislamika: Jurnal Psikologi Dan Psikologi Islam 12.2 (2015): 5-10.

${ }^{7}$ Noviana, Ivo. "Kekerasan seksual terhadap anak: dampak dan penanganannya." Sosio Informa 1.1 (2015).see also Sumera, Marchelya. "Perbuatan Kekerasan/Pelecehan Seksual Terhadap Perempuan."Lex et Societatis 1.2 (2013).see also Arliman, Laurensius. "Reformasi Penegakan Hukum Kekerasan Seksual Terhadap Anak Sebagai Bentuk Perlindungan Anak Berkelanjutan." Kanun Jurnal Ilmu Hukum 19.2 (2017): 305-326. See also Simbolon, Dewi Fiska. "Kurangnya Pendidikan Reproduksi Dini Menjadi Faktor Penyebab Terjadinya Pelecehan Seksual Antar Anak." Soumatera Law Review 1.1 (2018): 43-66.

${ }^{8}$ Hamka Haq. 2002, Filsafat Ushul Fiqh, Yayasan Al -Ahkam, Makassar, p. 20. see also Badawi, Ahmad. "Politik Hukum Islam: Teori Keberlakuan Hukum Islam di Indonesia." Al-Fikru 12.2 (2019).see also Suryani, Lilis. Sanksi bagi pelaku aborsi hamil diluar nikah perspektif Hukum Pidana Islam. Diss. UIN Sunan Gunung Djati Bandung, 2019.
} 
name for an act that Syara prohibits', both about the soul, property and other than the soul and property. ${ }^{1}$ So, the meaning of jinayah is all actions that are forbidden. Prohibited actions are actions that are prohibited or prevented.

Based on the laws and regulations in Aceh all statutory products formed jointly by the executive and legislature (Governor and House of Representatives of Aceh) are called Qanun Aceh. Qanun in Aceh consists of two categories, namely Qanun which regulates the material of government administration, and Qanun which regulates the material for the implementation of Acehnese life. Qanun Law Jinayah belongs to the category of qanun related to the maintenance of Acehnese life.

The Law of the Republic of Indonesia number 11 of 2006, requires several organic laws and regulations, especially Qanun Aceh to implement Islamic sharia. Qanun serves as operational legislation to make Sharia law as positive legal material.

\section{Model of Protection Against Children of Sexual Offenders According to Oanun Jinayah Aceh}

Qanun Jinayah Aceh is a rule of law in the framework of crime prevention in Aceh using the principles of Islamic law. This Qanun not only applies to adult criminals but also applies to children who commit criminal acts. Article 67 specified that if a child who has reached the age of 12 years but has not reached the age of 18 years or is unmarried commits a criminal act, then the child may be subject to 'Uqubat at most 1/3 of the 'Uqubat that has been determined for adults and or returned to his parents/guardians or placed in a place provided by the Government of Aceh or the Regency / City Government. The provisions of the above article seem to place the child as the perpetrator because against the child perpetrator of the crime (jarimah) must be sanctioned (uqubah) both uqubat whip and prison one-third of the uqubah against adults. Based on the results of research that has been conducted in Banda Aceh City, Aceh Besar Regency, and Aceh Tamiang Regency, the child still gets the protection of his rights as a child even though he has done jarimah. The model of legal protection against child abusers that have been carried out by law enforcement are:

1. Protection through diversion

Qanun jinayah law does not recognize diversion in the settlement of child cases, because qanun only regulates material law, does not regulate formal law, and formal law is regulated separately in other qanuns. However, Qanun Law Jinayah accommodates the process of examining the child perpetrators of crimes by using provisions in the Law on the Criminal Justice System of Children (SPPA). Article 66 Qanun of Jinayah Law specified that: If a child who has not reached the age of 18 years does jarimah or allegedly performs jarimah, then the child is carried out an examination guided by the laws and regulations regarding juvenile criminal justice. Article 7 paragraph 1 of the Law of the Republic of Indonesia Number 11 of 2012 concerning the Criminal Justice System of Children explains that at the level of investigation, prosecution, and examination of child cases in the District Court must be attempted diversion. At the investigation stage, the case of the child as a sexual abuser must be resolved through diversion in the family and social care, which is an environment that provides a sense of security by being monitored by the officers who have been determined, so that the child is no longer a victim. According to Suprianto, at the investigative stage of sexual abuse cases, child suspects get legal protection through settlement efforts outside the criminal justice process. So the child suspect is not directly examined by investigators but is attempted to resolve it by peaceful means through the family. Where the process of peaceful settlement is carried out without involving elements of the police because the case has been excluded from the legal process. However, after the diversion effort is completed, it needs to be made in a news event, then submitted to the court to decide that the sexual abuse case has been resolved by diversion. ${ }^{2}$

2. Protection from whip sanctions

The Aceh jinayah law implicitly does not specify how the application of caning sanctions to children who are perpetrators of sexual crimes, article 67 only stipulates that the application of caning sanctions to children can be applied to a third of the number of sanctions against adults. Based on the results of the study, the application of caning sanctions was only applied to children if the child was over 15 years old. According to Surya, if the sexual harassment case cannot be resolved by diversion at the judicial level, the judge after going through the judicial process will not impose a caning sanction on the child who is the perpetrator of sexual abuse. This is because children under the age of fifteen years are still unstable, their minds are not yet full to accept the sanctions imposed by law so that the actions taken by the child cannot be fully accounted for, then the application of the law should not be carried out optimally. ${ }^{3}$

\footnotetext{
${ }^{1}$ Abdul Kadir Audah, At-Tasyrik Al-Jina 'iy Al-Islamy, Darul Kitab Al-Araby,Juzu.I, Bairut, p. 67 see also Surbakti, Natangsa. "Penegakan Hukum Pidana Islam (Jinayah) Di Provinsi Nanggroe AcehDarussalam." Jurnal Media Hukum 17.2 (2010).see also Mubarok, Nafi. "Tujuan Pemidanaan dalam Hukum Pidana Nasional dan Fiqh Jinayah." Al-Qānūn: Jurnal Pemikiran dan Pembaharuan Hukum Islam 18.2 (2015): 296-323.

${ }^{2}$ Suprianto, Kasubnit PPA Polresta Banda Aceh, Personal Interview, date 11 November 2020

${ }^{3}$ Surya, Child Judge in court Syar'iyyah Kota Banda Aceh, Personal interview, date 10 November 2020
} 


\section{Protection of children's rights}

Children as perpetrators of criminal acts are still fulfilled their rights both in the judicial process and after being executed to the child development institution. In the process of child justice, the perpetrator of sexual abuse is still fulfilled his rights such as the right to attend education in the school where the child attends school. The child suspect will be escorted to school by officers and will get an education fulfilled even though he is in the judicial process. ${ }^{1}$

If the verdict has permanent legal force, the child will be executed to the Aanak Special Penitentiary to undergo development or rehabilitation, the child will still get his rights both the right to education and the right to be trained certain skills or the right to attend religious education. So the child after rehabilitation can return to the community or his family with a health condition. ${ }^{2}$

Children's Criminal Justice in Indonesia serves as a judicial system that protects children without having to sacrifice the interests of the community in upholding justice because the purpose of juvenile criminal justice is essentially no different from other courts. Children's criminal justice hearings are also known as child trials where law enforcement officers on duty and authorized to examine, disconnect and resolve child regulations based on the provisions of the laws and regulations are as follows:

1. Article 1 number 1 of the Law of the Republic of Indonesia Number 11 of 2012 concerning the Juvenile Criminal Justice System of the Children's Criminal Justice System is the entire process of resolving child cases that face the law, starting from the investigation stage to the guidance stage after undergoing criminal proceedings."

2. Article 16 of the Law of the Republic of Indonesia Number 11 of 2012 concerning the Juvenile Criminal Justice System The provisions of the Criminal Procedure Law apply also in the event of juvenile criminal justice unless otherwise specified in this Law."

One of the law enforcement efforts carried out by the state is through juvenile justice as a state effort in providing protection to children who commit crimes and educating children without having to ignore the enforcement of justice because juvenile justice is made to re-educate and improve the attitude and behavior of the child so that the child can leave the bad behavior that he has done, Child protection is carried out by providing guidance and education in the framework of rehabilitation and resocialization to be the foundation of juvenile criminal justice. Article 1 point 1 a law of the Republic of Indonesia Number 4 of 1979 on Child Welfare explains that "the welfare of children is a child's life and livelihood that can guarantee the growth and development of it reasonably both spiritually, physically and socially because realizing the welfare of children in upholding justice is the main duty of the Child Justice according to the Law of the Criminal Justice System of children because juvenile criminal justice is designed not only. Limited to imposing criminal sanctions only but also providing protection for the future of children, the philosophy of juvenile criminal justice is to realize the welfare of children so that the laws and regulations of child welfare and the juvenile criminal justice system are interrelated. Therefore, the model of protection of child abusers that has been implemented by law enforcement in the process of juvenile criminal justice in Aceh Province is following the philosophy of juvenile criminal justice.

\section{CONCLUSION}

The model of legal protection against child abusers according to the jinayah law that has been applied by law enforcement in Aceh Province, in the form of; protection through diversion, protection against the application of flogging sanctions, and protection of other children's rights, both the right to education, the right to religious guidance and the right to work. It is expected of the Aceh government to perfect the Jinayah Law Qanun especially against child protection provisions so that the material in Qanun Jinayah Law can be applied consistently by law enforcement.

\section{REFERENCES}

A. Buku/Kitab

Abdul Kadir Audah, At-Tasyrik Al- Jina 'iy Al-Islamy, Darul Kitab Al-Araby,Juzu.I, Bairut, Al-Kahlani, Muhammad Ismail. 1960, Subul as-Salam. Syarh Bulugh al- Maram, juz III, Mustafa al-Babi alHalabi, Mesir.

Hadi Supeno. 2010, Kriminalisasi Anak, Gramedia Pustaka Utama, Jakarta, Hamka Haq. 2002, Filsafat Ushul Fiqh, Yayasan Al -Ahkam, Makassar, Maidin Gulto m, Perlindungan Hukum Terhadap Anak, Refika Aditama, Bandung, 2008 Marlina. 2009, Peradilan Pidana Anak di Indonesia, Refika Aditama, Bandung, Poerwadarminta. 1984, Kamus Umum Bahasa Indonesia, Balai Pustaka; Armico, Jakarta,

\footnotetext{
${ }^{1}$ Taqdir, Prosecutor to the Jantho State Prosecutor's Office, Aceh Besar, personal interview, date 1 December 2020

${ }^{2}$ Taqdir Prosecutor to the Jantho State Prosecutor's Office, personal interview, date 1 Desember 2020
} 
Ronny Hanitjo Soemitro.2005. Metode Penelitian Hukum.Jakarta, Ghalia Indonesia, Sayyid Sabiq. 1986, Fiqh Sunnah, Jilid. 3, Toha Putra, Semarang,

Singgih Gunarso, Ny.dan Singgih Gunarso. 1985, Psikologi Remaja, Gunung Mulia, Jakarta.

Waluyadi. 2009, Hukum Perlindungan Anak, Mandar Maju, Bandung,

Mushaddiq, Nur Wahid. 2015, Tinjauan Yuridis terhadap Eksploitasi Seksual pada Anak Berdasarkan Hukum Perlindungan Anak dan Hukum Islam. Disertasi, Universitas Islam Negeri Alauddin Makassar,

Prasetyo, Harsanto Diyan. 2012, Kebijakan Hukum Pidana Dalam Upaya Perlindungan Hukum Terhadap Anak Pelaku Tindak Pidana (Juvenile Deliquency). Disertasi, Universitas Diponegoro,

Suryani, Lilis. 2019, Sanksi bagi pelaku aborsi hamil diluar nikah perspektif Hukum Pidana Islam. Diss. UIN Sunan Gunung Djati Bandung,

Aperani, Rika. "Hukum Pertanggungjawaban Pidana Anak Dalam Batasan Usia (Studi Analisis Hukum Pidana Islam dan Undang-Undang Nomor 11 Tahun 2012)." (2020).

Arliman, Laurensius. "Reformasi Penegakan Hukum Kekerasan Seksual Terhadap Anak Sebagai Bentuk Perlindungan Anak Berkelanjutan." Kanun Jurnal Ilmu Hukum 19.2 (2017):

Badawi, Ahmad. "Politik Hukum Islam: Teori Keberlakuan Hukum Islam di Indonesia." Al-Fikru 12.2 (2019).

Fitriani, Rini. "Peranan Penyelenggara Perlindungan Anak Dalam Melindungi Dan Memenuhi Hak-Hak Anak." Jurnal Hukum Samudra Keadilan 11.2 (2016)

Hambali, Azwad Rachmat. "Penerapan diversi terhadap anak yang berhadapan dengan hukum dalam sistem peradilan pidana." Jurnal Ilmiah Kebijakan Hukum 13.1 (2019)

Hartoyo, Nuri, Herman Fikri, and Adi Purnama. "Perlindungan Hukum Terhadap Anak Yang Berhadapan Dengan Hukum Melalui Restoratif Justice." Lex Librum: Jurnal Ilmu Hukum (2020)

Hermawati, Nety. "Kejahatan Anak Menurut Hukum Pidana Positif dan Hukum Pidana Islam." Istinbath: Jurnal Hukum 12.1 (2015)

Lukman"Penentuan Dewasa Menurut Hukum Islam Dan Berbagai Disiplin Hukum." Kordinat| Jurnal Komunikasi Antar Perguruan Tinggi Agama Islam 15.2 (2016):

Lukman, Lukman. "Relevansi Hukum Islam Dan Hukum Positif Tentang Usia Dewasa Dalam Perkawinan." Qiyas: Jurnal Hukum Islam dan Peradilan 4.1 (2019).

Mahfiana, Layyin. "Perlindungan hukum Terhadap tersangka anak sebagai upaya melindungi hakanak." Jurnal Muwâzâh 3.1 (2011).

Meily dkk., Perlindungan Hukum Terhadap Hak Anak Pelaku Tindak Pidana Pemerkosaan Dalam Sistem Peradilan Pidana, e Jurnal Katalogis, Vol. 5, No. 2, Februari2017.

Mubarok, Nafi. "Tujuan Pemidanaan dalam Hukum Pidana Nasional dan Fiqh Jinayah."Al Qānūn: Jurnal Pemikiran dan Pembaharuan Hukum Islam 18.2 (2015)

Nahrowi, Nahrowi. "Penentuan Dewasa Menurut Hukum Islam Dan Berbagai Disiplin Hukum." Kordinat| Jurnal Komunikasi Antar Perguruan Tinggi Agama Islam 15.2 (2016):

Noviana, Ivo. "Kekerasan seksual terhadap anak: dampak dan penanganannya." Sosio Informa 1.1 (2015).

Prasetyo, Andik. "Perlindungan Hukum Bagi Anak Pelaku Tindak Pidana." Mizan: Jurnal Ilmu Hukum 9.1 (2020):

Rahayu, Sri. "Diversi Sebagai Alternatif Penyelesaian Perkara Tindak Pidana Yang Dilakukan Anak Dalam Perspektif Sistem Peradilan Pidana Anak." Jurnal Ilmu Hukum Jambi 6.1 (2015)

Sekhroni, Sekhroni. "Criminal Liability dan Diversi Terhadap Tindak Pidana Anak dalam Sistem Peradilan Anak di Indonesia." Unifikasi: Jurnal Ilmu Hukum 3.1 (2016).

Simatupang, Taufik H. "Sistem Hukum Perlindungan Kekayaan Intelektual dalam rangka Meningkatkan Kesejahteraan Masyarakat." Jurnal Penelitian Hukum De Jure 17.2 (2017) Akbar, Amellia Putri. Pelanggaran HAM dalam Pemidanaan (Perbandingan Hukuman Cambuk dengan Penjara). Disertasi, UIN Ar-Raniry Banda Aceh, 2017.

Simbolon, Dewi Fiska. "Kurangnya Pendidikan Reproduksi Dini Menjadi Faktor Penyebab Terjadinya Pelecehan Seksual Antar Anak." Soumatera Law Review 1.1 (2018):

Siregar Risdalina, Pengaruh Mass Media Terhadap Kenakalan Remaja Ditinjau dari Psikologi Kriminal, "Jurnal Ilmiah Advokasi, 5.2 (2017), halaman 94-109

Sumera, Marchelya. "Perbuatan Kekerasan/Pelecehan Seksual Terhadap Perempuan." Lex et Societatis 1.2 (2013).

Surbakti, Natangsa. "Penegakan Hukum Pidana Islam (Jinayah) Di Provinsi Nanggroe AcehDarussalam." Jurnal Media Hukum 17.2 (2010).

Suseni, Komang Ayu, and I. Made Gami Sandi Untara. "Upaya Penanggulangan Tindak Pidana Kekerasan Seksual Terhadap Anak."Pariksa 1.1 (2020). Rohmah, Nurur, et al. "Kekerasan Seksual Padaanak: Telaah Relasi Pelaku Korban Dan Kerentanan Pada Anak."Psikoislamika: Jurnal Psikologi Dan Psikologi Islam $12.2(2015)$

Unayah, Unung and Muslim Sabarisman, Fenomena Kenakalan Remaja dan Kriminalitas, "Sosio Informa”, 1.2. 
(2016).

Wahyudi, Dheny. "Perlindungan terhadap anak yang berhadapan dengan hukum melalui pendekatan restorative justice." Jurnal Ilmu Hukum Jambi 6.1 (2015)

Yudaningsih, Lilik Purwastuti, and Sri Rahayu. "Reformasi Perlindungan Hukum terhadap Anak Sebagai Pelaku Tindak Pidana dalam Peradilan Pidana di Indonesia." INOVATIF $\mid$ Jurnal Ilmu Hukum 6.2 (2013) 